\title{
PERAN AUDIT INTERNAL DALAM RANGKA PENCEGAHAN FRAUD (STUDI KASUS PT JAVA PRIMA ABADI)
}

\author{
Fitrianty Ningsih \\ Saifudin
}

Fakultas Ekonomi Universitas Semarang

Diterima: Agustus 2019, Disetujui: September 2019, Dipublikasikan: Oktober 2019

\begin{abstract}
This research was conducted at PT. Java Prima Abadi in Marketing Division. The purpose of this study is to analyze about how internal control in the company and fraud that occurs in this company.

This study uses qualitative methods, using triangulation of data sources namely observation, interviews, documentation and focus group discussions, and adequacy. The basic principles of information in this study were 4 people.

From the results of this study indicate that there are still some fraud problems in the company, the problems faced by PT. Java Prima Abadi is still a weak internal audit and there are multiple functions in the job description of the division of tasks to employees, it is necessary to improve internal control and supervision to avoid fraud.
\end{abstract}

Keywords: Fraud, Internal Audit, Internal Control

\begin{abstract}
Abstrak
Penelitian ini dilakukan di Perusahaan PT. Java Prima Abadi di Devisi Marketing. Tujuan Penelitian ini adalah menganalisis tentang bagaimana pengendalian internal dalam perusahaan dan kecurangan yang terjadi di dalam perusahaan ini.

Penelitian ini menggunakan metode kualitatif, dengan menggunakan triangulasi sumber data yaitu obeservasi, wawancara, dokumentasi dan focus group discussion, dan kecukupan (adequacy). Dasar prinsip informasi didalam penelitian ini ada 4 orang.

Dari hasil penelitian ini menunjukkan bahwa masih terdapat beberapa masalah kecurangan di dalam perusahaan, masalah yang dihadapi PT. Java Prima Abadi adalah masih lemahnya audit internal dan terdapat kerangkapan fungsi dalam job description pembagian tugas pada karyawan maka perlu ditingkatkannya pengendalian internal dan pengawasan agar tidak terjadi kecurangan.
\end{abstract}

Kata Kunci : Kecurangan, Audit Internal, Pengendalian Internal

\section{Pendahuluan}

Suatu perusahan sangat memerlukan adanya internal audit yang efektif, terutama diperusahaan menengah dan besar. Apalagi dengan akan diberlakukannya perdagangan bebas diantara Negara-negara diseluruh dunia, yang tidak lagi memperbolehkan adanya proteksi. 
Menurut Piket dalam Sukrisno Agoes (2014) Audit Internal adalah kegiatan assurance dan konsultasi yang independent dan objektif, yang dirancang untuk memberikan nilai tambah dan meningkatkan kegiatan-kegiatan operasi organisasi. Audit Internal membantu organisasi untuk mencapai tujuannya, melalui suatu pendekatan yang sistematis dan teratur untuk mengavaluasi dan meningkatkan efektivitas dari manajemen resiko, pengendalian dan proses tata kelola.

Audit internal merupakan suatu tahapan pengendalian guna menghindari penyelewengan, penyimpangan dan kecurangan (fraud) akan kesalahan dalam pekerjaan akuntansi, karena hasil dari pemeriksaan tersebut dapat diketahui dengan cepat dan benar bagaimana kondisi perusahaan yang sebenarnya sehingga dapat membantu pemimpin perusahaan dalam hal mengambil keputusan.

Audit internal menurut Sawyer dalam Desy (2009) adalah salah satu fungsi yang dibuat perusahaan dalam satu satuan usaha untuk memantau efektivitas kebijakan, dan prosedur lain yang berkaitan dengan pengendalian dan merupakan bagian dari alat organisasi perusahaan yang mempunyai fungsi baik dalam pengendalian akuntansi, maupun pengendalian fungsi manajemen, serta untuk mengecek apakah unsur - unsur internal bekerja sebagaimana mestinya.

Langkah - langkah dalam proses (process) audit internal terdiri dari perancangan pemeriksaan (audit plan), pengujian dan pengevaluasian informasi, menyampaikan hasil pemeriksaan, dan tindak lanjut (follow up). Oleh karena itu, dalam suatu perusahaan biasanya dibentuk satuan pengawas internal. Dengan adanya audit internal, diharapkan kegiatan perusahaan dapat berjalan dengan baik dan beban manajemen dalam melakukan tanggung jawab secara efektif dan efesien, agar tercapainya suatu tujuan perusahaan sesuai dengan yang diharapkan dan dalam hal ini dilakukan karena cukup kompleksnya kegiatan dalam perusahaan. Yang tak cukup kalah pentingnya untuk mencegah adanya tindakan kecurangan atau fraud upaya yang dapat dilakukan adalah dengan penerapan sistem pengendalian internal perusahaan yang diharapkan nantinya dapat menunjang pencegahan dan pemberantasan kecurangan atau fraud.

Pengendalian internal merupakan kegiatan yang sangat penting dalam pencapaian tujuan usaha. Pengendalian internal menjadi penting karena dengan menerapkan pengendalian internal, kegiatan bisnis perusahaan akan jadi efisien 
kemudian juga meminimalkan resiko kehilangan aset serta memastikan kepatuhan pada peraturan yang ada. Efisiensi pada aktivitas bisnis perusahaan itu penting karena perusahaan yang ingin mempertahankan dan mengembangkan bisninnya harus dapat melakukan kegiatan operasionalnya secara efektif, efesiensi dan ekonomis. COSO juga menyebutkan ada fungsi untuk meminimalkan resiko pencurian aset, seperti yang kita ketahui bahwa kerugian perusahaan terbesar adalah adanya pencurian aset perusahaan yang bisa berupa cash ataupun important file ( data pelanggan dan data supplier).

Menurut Norsain (2014), kecurangan merupakan satu dari berbagai permasalahan yang terjadi dalam lingkungan organisasi atau perusahaan. Praktek kecurangan itu dapat terjadi bahkan pada organisasi yang memiliki pengendalian internal yang baik sekalipun.Kecurangan atau fraud merupakan suatu kesalahan yang dilakukan secara sengaja. Dalam lingkup akuntansi, konsep kecurangan atau fraud merupakan penyimpangan dari prosedur akuntansi yang seharusnya diterapkan dalam suatu perusahaan. Penyimpangan tersebut akan berdampak pada laporan keuangan yang disajikan perusahaan, istilah fraud belum dikenal secara luas di Indonesia. Masyarakat Indonesia lebih mengenal segala bentuk penyelewengan dan penyalah gunaan jabatan atau kekuasaan untuk memperoleh keuntungan sebagai korupsi.Namun sebenarnya korupsi hanyalah salah satu bentuk dari praktik fraud.

Cressey (1950) dalam Rachmawati dan Marsono (2014) Kecurangan umumnya terjadi karena tiga hal utama, yaitu : adanya tekanan untuk melakukan penyelewengan, adanya kesempatan yang bisa dimanfaatkan serta adanya pembenaran akan tindakan tersebut. Kecurangan yang sering terjadi adalah ditemukan pada bagian marketing perusahaan, dengan tidak mencatat dan membuatkan nota pembayaran dari konsumen dan mengantongi uangnya, menunda penyetoran uang hasil penjualan pada hari yang sama, membuat nota fiktif penjualan kredit atas nama konsumen padahal telah terjadi transaksi tunai atau cash dan lain sebagainya.

Bagi perusahaan yang melakukan penjualan melalui marketing atau salesman dengan sistem sales kanvas atau sales yang membawa langsung barang yang untuk dijual ke konsumen atau pihak toko, sangat rentan terjadinya kecurangan terutama kecurangan pada saat sales melakukan penjualan secara tunai atau melakukan penagihan langsung tanpa melalui collector.Tindakan kecuranga ini sering terjadi pada berbagai macam perusahaan.Kecurangan ini biasanya dilakukan oleh divisi marketing atau sering 
disebut juga salesman. PT. Java Prima Abadi merupakan salah satu perusahaan yang bergerak dalam bidang manufaktur yang melakukan penjualan kopi “ Luwak White Koffie" baik dalam bentuk kemasan yang berisikan kopi bubuk dan juga kopi cair ready to drink dalam kemasan botol. Perusahaan ini memiliki dua cabang yang dibuka di Sayung Demak sebagai anak cabang perusahaan dan di Kaligawe Semarang sebagai HO atau kantor pusat. Pendapatan perusahaan ini diperoleh dari penjualan produk - produk yang dimiliki perusahaan, dan praktik penjualannya sepenuhnya dilakukan oleh sales kanvas baik secara tunai ataupun kredit dengan sistem penagihan yang diberikan jangka waktu 14 hari dari tanggal terbitnya nota penjualan untuk konsumen yang harus dilunasi. Penagihan yangdilakukan ke toko oleh sales kanvas dari perusahaan berjalan sesuai dengan jadwal kunjungan yang telah ada.

PT. Java Prima Abadi ini mempunyai tagihan secara kredit yang telah menunggak lama dan dapat dikatakan tidak tertagihkan kurang lebih selama 2 tahun yaitu dari tahun 2016 sampai dengan 2018. Ditemukan beberapa konsumen atau toko yang belum melunasi nota tagihan secara kredit.Sehingga mengakibatkan jumlah tagihan kredit terus bertambah dan ternyata sudah melewati tanggal jatuh tempo dan ditemukan nota tagihan kredit yang pola lakunya berubah - ubah tidak sesuai dengan jangka waktu yang diberikan perusahaan, sehingga perusahaan mengalami kerugian.

Setelah dilakukan roling area salesman dan pemeriksaan oleh bagian accounting perusahaan mengapa tagihan bisa meningkat dengan jumlah yang lumayan besar, ternyata penyebabnya dikarekan adanya tindakan kecurangan yang dilakukan oleh sales yang tidak melakukan pembayaran nota tagihan secara kredit yang telah jatuh tempo melebihi dari ketentuan yang diberikan oleh perusahaan dan ditemukan adanya pembuatan nota fiktif yang dilakukan oleh salesman dengan merekayasa penjualan secara cash atau tunai dirubah menjadi penjualan secara kredit. Adapun kerugian yang dialami oleh PT. Java Prima Abadi dalam kurun waktu 2016 sampai dengan 2018 sebagai berikut : 


\section{Tabel 1.1}

Daftar kerugian PT. Java Prima Abadi periode 2016 s/d 2018

\begin{tabular}{llll}
\hline No & Bulan & Konsumen & Jumlah Tagihan \\
\hline 1 & Januari & Pak Muh & Rp. 28.081.500,- \\
2 & Febuari & Pintar 1 & Rp. 10.296.550,- \\
3 & Maret & Iwan & Rp. 12.168.650,- \\
\hline & Total & & Rp. 50.546.700,- \\
\hline
\end{tabular}

Sumber : Rekap Nota PT. Java Prima Abadi

Dari data diatas menunjukkan jumlah kerugian perusahaan yang dilakukan oleh pihak sales dengan melakukan tindak kecurangan yang dilakukan dengan atas nama konsumen yang sebenarnya telah malakukan pembayaran tunai atau cash. Jumlah kerugian yang dialami oleh perusahaan ini cukup besar.Kecurangan yang dilakukan oleh sales perusahaan ini terjadi karena sistem pengendalian internal yang kurang baik pada karyawan ataupun terhadap perusahaan itu sendiri, sehingga dapat dengan mudahnya saja melakukan tindakan yang merugikan perusahaan dengan mengambil uang hasil tagihan nota penjualan perusahaan.

Dari kasus yang terjadi diperusahaan ini maka diperlukan adanya audit internal dan pengendalian internal yang baik pada perusahaan dimana audit internal dan pengendalian internal ini adalah cara yang dapat digunakan dalam mengantisipasi dan meminimalkan adanya tindakan kecurangan di perusahaan.

Berdasarkan penelitian terdahulu tentang audit internal dan pengendalian internal terhadap pencegahan fraud yang pernah dilakukan oleh Suginam (2017) dalam penelitiannya menyatakan bahwa pengaruh audit internal sangat memiliki peran yang besar didalam perusahaan untuk mengendalikan dan mengevaluasi aktivitas kegiatan perusahaan terutama dalam pencegahan fraud. Peran audit internal senantiasa mengevaluasi efektivitas sistem pengendalian dan memberikan rekomendasi intern perbaikan jika ditemukan kelemahan - kelemahan. Namun demikian, sebagai fungsi pengawasan, audit internal dituntut juga untuk mendeteksi fraud yang diyakini sedang atau telah terjadi. Di dalam perusahaan, audit internal tidak memiliki wewenang untuk langsung memberi perintah kepada pegawai, juga tidak dibenarkan untuk melakukan tugas - tugas operasional dalam perusahaan yang sifatnya di luar kegiatan pelaksanaan. Dijelaskan juga bahwa audit internal berpengaruh positif terhadap fraud. Pengendalian internal berpengaruh positif terhadap fraudakan tetapi hasil tidak signifikan.Kondisi ini 
memperlihatkan bahwa keberhasilan fraud tidak hanya seluruhnya ditentukan oleh pengendalian internal.

Menurut Thetty (2017) mengatakan bahwa pengaruh internal audit dan pencegahan fraud terhadap kinerja keuangan perusahaan berdasarkan prosentase yang diperoleh dan dihubungkan dengan kriteria yang telah ditentukan, dapat disimpulkan bahwa audit internal dan pencegahan fraud belum berpengaruh terhadap kinerja keuangan. Pengaruh internal audit dan pencegahan fraud terhadap kinerja keuangan terdapat pengaruh yang signifikan dari peran audit internal terhadap pencegahan kecurangan.

\section{Landasan Teori}

\section{Pengertian Audit Internal}

Menurut A. Arens, dkk (2011) : “Auditing is the accumulation and evaluation of evidence about information to determinateand report on the degree of correspondence between the information and established criteria. Auditing should be done by ancompetent person".

Pengertian auditing tersebut adalah pengumpulan dan evaluasi bukti tentang informasi untuk menentukan dan melaporkan derajat antara informasi itu dan kriteria yang ditetapkan. Auditing harus dilakukan oleh orang yang kompeten dan independen.

Audit internal bertindak sebagai penilai independen untuk menelaah operasional perusahaan dengan mengukur dan mengevaluasi kecukupan kontrol serta efisiensi dan efektifitas kinerja perusahaan sebagai bentuk jasa yang diberikan pada perusahaan. Audit internal mempunyai peranan yang penting dengan pengelolaan perusahaan dan resiko-resiko terkait dalam menjalankan usaha.

\section{Jenis-jenis Audit}

Menurut Sukrisno Agoes (2004), ditinjau dari jenis pemeriksaan, audit bisa dibedakan atas :

1. Management Audit (Operasional Audit)

Suatu pemeriksaan terhadap kegiatan operasi suatu perusahaan, termasuk kebijakan akuntansi dan kebijakan operasional yang telah ditentukan oleh manajemen, untuk mengetahui apakah operasi tersebut sudah dilakukan secara efektif, efesien dan ekonomis. 


\section{Compliance Audit (Pemeriksaan Ketaatan)}

Pemeriksaan yang dilakukan untuk mengetahui apakah perusahaan sudah mentaati peraturan-peraturan dan kebijakan-kebijakan yang berlaku, baik yang ditetapkan oleh pihak intern perusahaan (manajemen, dewana komisaris) maupun pihak ekstern ( Pemerintah Bapepam, Bank Indonesia, Direktorat Jendral Pajak, dan lain-lain).

\section{Internal Audit (Pemeriksaan Internal)}

Pemeriksaan yang dilakukan oleh bagian internal audit perusahaan, baik terhadap kebijakan manajemen yang telah ditentukan. Pemeriksaan yang dilakukan internal auditor biasanya lebih rinci dibandingkan dengan pemeriksaan umum yang dilakukan oleh KAP (Kantor Akuntan Publik). Internal auditor biasanya tidak memberikan opini terhadap kewajaran laporan keuangan, karena pihak-pihak diluar perusahaan tidak independen.

\section{Computer Audit}

Pemeriksaan oleh KAP terhadap perusahaan yang memproses data akuntansinya dengan menggunakan EDP (Electronic Data Processing) sistem.

\section{Tujuan Audit Internal}

Tujuan pemeriksaan internal adalah memberikan nilai tambah dan melakukan perbaikan operasi organisasi. Tujuan pemeriksaan internal membantu organisasi dalam mencapai tujuannya dengan melalui pendekatan yang sistematis, disiplin untuk mengevaluasi dan melakukan atas keefektivan manajemen resiko, pengendalian dan proses yang jujur, bersih dan baik.

\section{Prosedur Audit Internal}

Adapun langkah-langkah dalam audit intern menurut Arens (2008) adalah sebagai berikut :

1. Tahap Persiapan Pemeriksaan

2. Tahap Pengujian Pengendalian Intern

3. Tahap Pemeriksaan Lanjutan

4. Tahap Pelaporan

5. Tahap Tindak Lanjut Hasil Pemeriksaan 


\section{Sistem Pengendalian Internal}

Krismiaji (2005) mendefinisikan pengendalian internal adalah rencana organisasi dan metode yang digunakan untuk menjaga atau melindungi aktiva, menghasilkan informasi yang akurat dan dapat dipercaya. Sedangkan menurut James (2007) Pengendalian internal adalah berbagai kebijakan, praktik dan prosedur yang diterapkan oleh perusahaan untuk mencapai empat tujuan umumnya yaitu :

1. Menjaga aktiva perusahaan baik berupa kekayaan berwujud maupun kekayaan yang tidak berwujud.

2. Memastikan akurasi dan keandalan catatan serta informasi akuntasi, informasi menjadi dasar pembuatan keputusan.

3. Mendorong efisiensi dalam operasioanal perusahaan, efisiensi merupakan suatu perbandingan antara besarnya pengorbanan dan hasil yang diperoleh. Perusahaan yang efisien akan lebih mudah mendapatkan laba yang besar.

4. Mengukur kesesuaian dengan kebijakan serta prosedur yang diterapkan oleh pihak manajemen. Secara berkala manajemen telah menetapkan tujuan yang akan dicapai oleh perusahaan. Didalam perusahaan terdapat banyak orang yang memiliki berbagai kepentingan, namun kepentingan mereka tidak boleh bertentangan dengan kepentingan perusahaan. Disisi lain manajemen juga harus menetapkan tujuan yang tidak terlalu tinggi dan juga tidak terlalu rendah.

\section{Tujuan Pengendalian Internal}

Tujuan pengendalian internal adalah menyediakan keyakinan yang menandai bahwa :

1. Aset telah dilindungi dan digunakan untuk keperluan bisnis.

2. Informasi bisnis akurat.

3. Karyawan dan manajer mematuhi hukum dan peraturan yang berlaku.

Pengendalian internal dapat melindungi aset perusahaan dari pencurian, kecurangan, penyalahgunaan, atau kesalahan penempatan.Salah satu pelanggaran pengendalian internal yang paling serius adalah kecurangan yang dilakukan oleh karyawan.

\section{Keterbatasan Pengendalian Internal}

Sistem pengendalian internal hanya dapat memberikan keyakinan memadai untuk menjaga untuk menjaga aset, pengolahan informasi yang akurat, dan kepatuhan 
terhadap hukum dan peraturan. Dengan kata lain, pengendalian internal tidak menjadi jaminan. Hal ini disebabkan faktor - faktor berikut :

1. Pengendalian elemen manusia

Elemen manusia mengakui bahwa pengendalian internal yang diterapkan dan digunakan oleh manusia.Akibatnya, kesalahan manusia dapat terjadi karena kelelahan, kebingungan, atau salah perhitungan.

2. Pertimbangan biaya dan manfaat

Pertimbangan biaya dan manfaat ini mengakui bahwa biaya pengendalian internal tidak boleh melebihi manfaatnya.Namun yang sering terjadi pada suatu perusahaan adalah diakibatkan oleh elemen manusia, berawal dari kesalahan yang sering dilakukan atau kecerobohan yang tidak disengaja menimbulkan salah perhitungan dengan begitu pihak yang melakukan kesalahan harus menggantinya karena keterbatasan dari elemen manusia ini maka menimbulkan gagasan untuk melakukan kecurangan (fraud).

\section{Pengertian Fraud}

Fraud (kecurangan) merupakan suatu tindakan yang dilakukan secara sengaja untuk tujuan pribadi atau kelompok, dimana tindakan yang disengaja tersebut telah menyebabkan kerugian bagi pihak tertentu. Dalam kata fraud itu sendiri dapat diartikan dengan berbagai makna yaitu :

1. Kecurangan

2. Kebohongan

3. Penipuan

4. Kejahatan

5. Penggelapan barang - barang

6. Manipulasi data

7. Rekayasa informasi

8. Mengubah opini dengan memutar balik kan fakta yang ada

9. Menghilangkan barang bukti secara sengaja.

Menurut Siegel dan Shim dalam Fahmi (2011) fraud (kecurangan) merupakan tindakan yang disengaja oleh perorangan atau kesalah untuk menipu orang lain yang menyebabkan kerugian khususnya terjadi misrepresentation ( penyajian yang keliru ) untuk merusak, atau dengan maksud menahan data bahan yang diperlukan untuk 
pelaksanaan keputusan yang terdahulu. Bentuk - bentuk Fraud Sukrisno Agoes (2014) yaitu :

\section{Internal Eror}

Kekeliruan bisa disengaja dengan tujuan untuk menguntungkan diri sendiri dalam bentuk window dreesing( merekayasa laporan keuangan supaya lebih terlihat lebih baik).

\section{Collusion}

Kecurangan yang dilakukan oleh lebih dari satu orang dengan cara bekerja sama dengan tujuan untuk menguntungkan orang - orang tersebut, biasanya merugikan perusahaan atau pihak ketiga.

\section{International Misrepresentation}

Memberi saran bahwa suatu itu benar, padahal itu salah, oleh seseorang yang mengetahui bahwa hal itu salah.

\section{Negligent Misrepresentation}

Pernyataan bahwa hal ini salah oleh seseorang yang tidak mempunyai dasar yang kuat menyatakan bahwa hal itu betul.

\section{False Promises}

Suatu janji yang diberikan tanpa keinginan untuk memenuhi janji tersebut.

\section{Employee Fraud}

Kecurangan yang dilakukan pegawai untuk menguntungkan dirinya sendiri.

\section{Management Fraud}

Kecurangan yang dilakukan oleh manajemen sehingga merugikan pihak lain, termasuk pemerintah.

\section{Organized Crime}

Kejahatan yang terorganisasi.

\section{Computer Crime}

Kejahatan dengan memanfaatkan teknologi computer, sehingga si pelaku bisa mentransfer dana dari rekening orang lain ke rekeningnya sendiri.

10. White collar crime

Kejahatan yang dilakukan orang - orang berdasi (kalangan atas). 


\section{Gejala Timbulnya Fraud}

Menurut Suginam (2017) gejala timbulnya fraud dibagi menjadi dua yaitu :

1. Gejala Fraud Manajemen :

a. Ketidak cocokan diantara manajer puncak.

b. Moral dan motivasi karyawan rendah.

c. Tingkat complain yang tinggi terhadap perusahaan dari pihak konsumen, pemasok atau badan otoritas.

d. Terdapat kelebihan persediaan yang signifikan.

2. Gejala Fraud Pegawai :

a. Pengeluaran tanpa dokumen pendukung.

b. Kekurangan barang yang diterima.

c. Kemahalan barang yang dibeli.

d. Faktor ganda dan penggantian mutu barang.

e. Penghancuran, penghilangan, pengrusakan dokumen pendukung pembayaran.

\section{Metode Penelitian}

\section{Jenis Penelitian}

Penelitian ini adalah penelitian jenis Case Study (studi kasus).Penelitian ini menggunakan bukti empiris yang berupa data, bukan berdasarkan angka tapi berdasarkan dokumen dan bukti transaksi yang dikaitkan langsung dengan teori yang telah disajikan pada tinjauan teoritis, dengan begitu peneliti berusaha mempelajari permasalahan yang terjadi.

Penelitian ini membutuhkan data kualitatif.Data kualitatif merupakan data yang berhubungan dengan karakteristik yang berwujud pertanyaan atau berupa kata - kata yang bertujuan menjelaskan tentang peran audit internal dan pengendalian internal terhadap pencegahan fraudpada PT. Java Prima Abadi, khususnya bagaimana kecurangan (fraud) ini dapat terjadi.

\section{Jenis Data Penelitian}

Data yang ada dalam penilitan ini adalah terdiri dari dua sumber data yang di kelompokan menjadi : 


\section{Data Primer}

Data yang di peroleh dan kumpulkan secara langsung dari sumber datanya oleh peniliti.Data primer ini di peroleh dari wawancara lisan dan tertulis, observasi dan dokumentasi yang di lakukan atau di ambil dari PT. Java Prima Abadi.

\section{Data Sekunder}

Data yang di peroleh bersumber dari berbagai sumber telaah yang ada.Diantaranya dari catatan atau memo, literatur, jurnal penilitian terdahulu dan lain sebagainya.

\section{Tempat dan Waktu Penelitian}

Tempat dan waktu penelitian terkait dengan lokasi penelitian di lakukan pada saat penelitian ini berlangsung yaitu dilakukan dari bulan maret sapai dengan mei 2019 dan di lakukan setelah jam kerja telah selesai yaitu di mulai pukul 16.00 WIB dan di lakukan di area kantor PT. Java Prima Abadi.

\section{Subyek dan Obyek Penelitian}

Subyek penelitian pada studi kasus ini adalah informan yang berasal dari karyawan baik dari admin, stockis maupun marketing pada PT. Java Prima Abadi sebagai sumber data penelitian yang di nilai mengerti, memahami dan menguasai informasi atau data yang di perlukan oleh peneliti.

Obyek penelitian ini adalah terdiri dari satu informan kunci selaku audit internal dan ada empat informan pendukung,yaitu yang terdiri dari dua salesdan salah satunya yang terindikasi melakukan kecurangan, seorang Team Leader dari sales perusahan dan direktur atau manager dari perusahaan PT. Java Prima Abadi.

\section{Metode Pengumpulan Data}

\section{A. Wawancara Lisan dan Wawancara Tertulis}

Wawancara lisan dan tertulis ini dilakukan pada satu informan kunci dan empat informan pendukung yang berasal dari karyawan PT. Java Prima Abadi.

Wawancara lisan di buktikan dengan rekaman wawancara yang kemudian disalin dalam bentuk teks tertulis.Wawancara tertulis ini dapat dibuktikan dengan tulisan tangan informan pada daftar pertanyaan wawancara tertulis. 


\section{B. Observasi}

Observasi dilakukan dengan cara mengamati secara langsung perilaku individu yang di sini difokuskan pada karyawan marketing dan peniliti berinteraksi langsung baik pada jam kerja di lingkungan PT. Java Prima Abadi ataupun di luar jam kerja setelah jam kantor selesai.

C. Dokumentasi

Dokumentasi yang digunakan peneliti adalah catatan administrasi berupa nota manual dan alat bantu yang di gunakan dalam penelitian ini adalah kamera handphone yang berfungsi sebagai alat perekam audio maupun video bisa untuk bukti bahwa memang benar - benar melakukan observasi dan wawancara secara langsung dan foto sebagai dokumen pendukung dalam penelitian ini.

\section{Teknik Analisi Data}

Setelah semua data dikumpulkan maka langkah selanjutnya adalah menganalisis data, sehingga data tersebut dapat di tarik suatu kesimpulan.Teknik analisis data skripsi studi kasus terdiri dari uji kredibilitas data dan narasi data.

\section{A. Uji Kredibilitas Data}

Uji kredibilitas data dalam penelitian studi kasus menggunakan teknik triangulasi. Triangulasi adalah teknik pengujian kredibilitas data yang memanfaatkan sesuatu yang lain di luar data itu untuk keperluan pengecekan atau suatu pembanding terhadap data itu. Teknik triangulasi yang digunakan dalam penelitian studi kasus ini adalah triangulasi sumber dan triangulasi metode.

\section{Triangulasi Sumber}

Triangulasi sumber adalah langkah pengecekan kembali data - data yang di peroleh dari informan dengan cara membandingkan data atau informasi yang diperoleh dari informasi kunci dengan informan pendukung. Peneliti mengajukan butir pertanyaan yang sama kepada seluruh informan. Dari data informan tersebut dapat dideskripsikan dan dikategorikan mana pandangan yang sama, mana pandangan yang berbeda, dan mana spesifikasi dari informan data tersebut.

\section{Triangulasi Metode}

Triangulasi metode yaitu dengan melakukan pengecekan data penelitian dengan teknik pengumpulan data yang berbeda yakni wawancara, observasi dan dokumentasi sehingga data bersifat kredible. Dari data yang telah dianalisis akan menghasilkan 
suatu kesimpulan yang selanjutnya diperoleh kebenaran. Dari hasil observasi dan wawancara tertulis diatas diperoleh kebenaran yang dapat disimpulkan, dan membuktikan bahwa kecurangan yang terjadi di dalam perusuhaan disebabkan karena pembuatan nota fiktif yang dilakukan oleh seles.Informasi ini di cross-check dengan metode observasi dan dokumentasi berupa data nota penjualan tagihan yang tidak tertagihkan.

B. Narasi Data

Apabila data di nilai kredibel, maka selanjutnya peneliti menarasikan data tersebut sesuai aspek yang di teliti.Narasi adalah suatu bentuk pengembangan paragraf pada sebuah karangan atau karya tulis dimana di dalamnya menjelaskan tentang rangkaian peristiwa secara runut dari waktu kewaktu mulai dari awal, tengah, hingga akhir.

Adapun tujuan membuat narasi adalah untuk menyampaikan informasi sehingga memperluas pengetahuan atau wawasan audiens serta untuk membagikan suatu pengalaman agar audiens turut merasakan pengalan tersebut.Melalui narasi data di atas, peneliti menggambarkan obyek penelitian secara rinci, tentang rangkaian peristiwa secara berurutan dari awal hingga akhir fenomena yang terjadi pada PT. Java Prima Abadi.

\section{Hasil dan Pembahasan}

\section{Bentuk Kecurangan ( fraud ) yang terjadi pada PT. Java Prima Abadi}

Berikut ini ringkasan hasil wawancara dengan beberapa informan tentang bagaimana bentuk kecurangan terhadap PT. Java Prima Abadi.

\section{Tabel 3.1}

Wawancara Tertulis

\begin{tabular}{|c|c|c|c|c|c|}
\hline \multirow[b]{2}{*}{ Pertanyaan } & \multicolumn{4}{|c|}{ InformanKunci } & \multirow[b]{2}{*}{ Verifikasi } \\
\hline & $\begin{array}{c}\text { Informan } 1 \\
\text { (Elen) }\end{array}$ & $\begin{array}{c}\text { Informan } 2 \\
\text { (Irianto) }\end{array}$ & $\begin{array}{c}\text { Informan } 3 \\
\text { (Pety) }\end{array}$ & $\begin{array}{c}\text { Informan } 4 \\
\text { (Agus) }\end{array}$ & \\
\hline $\begin{array}{l}\text { 1.Apa saja } \\
\text { bentuk } \\
\text { kecurangan } \\
\text { yang terjadi } \\
\text { pada PT. Java }\end{array}$ & $\begin{array}{l}\text { 1. Membuat } \\
\text { nota fiktif } \\
\text { pembayara } \\
\mathrm{n} \text { tunai } \\
\text { menjadi }\end{array}$ & $\begin{array}{l}\text { Pembuatan } \\
\text { nota fiktif } \\
\text { diatas } \\
\text { namakan } \\
\text { toko yang }\end{array}$ & $\begin{array}{l}\text { 1. Mangkir } \\
\text { dalam jam } \\
\text { kerja yang } \\
\text { digunakan } \\
\text { untuk }\end{array}$ & $\begin{array}{l}\text { 1. Pemalsuan } \\
\text { tandatangan } \\
\text { di nota } \\
\text { penjualan . }\end{array}$ & $\begin{array}{l}\text { Bentuk } \\
\text { kecurangan } \\
\text { yang terjadi } \\
\text { pada } \\
\text { perusahaan }\end{array}$ \\
\hline
\end{tabular}




\begin{tabular}{|c|c|c|c|c|c|}
\hline Prima Abadi? & $\begin{array}{l}\text { piutang. } \\
\text { 2. Melipat } \\
\text { gandakan } \\
\text { jumlah } \\
\text { tagihan } \\
\text { yang diatas } \\
\text { namakan } \\
\text { toko } \\
\text { menjadi } \\
\text { dua kali } \\
\text { lipat dari } \\
\text { tagihan } \\
\text { awal. }\end{array}$ & $\begin{array}{l}\text { bertransaksi } \\
\text { secara tunai. }\end{array}$ & $\begin{array}{l}\text { kepentingan } \\
\text { pribadi } \\
\text { 2. Meminjam } \\
\text { barang } \\
\text { penjualan } \\
\text { kepada } \\
\text { teman sales } \\
\text { satu } \\
\text { perusahaan } \\
\text { 3. Menggunak } \\
\text { an rekening } \\
\text { pribadi } \\
\text { sebagai alat } \\
\text { pembayaran. } \\
\text { 4. Membuat } \\
\text { nota tagihan } \\
\text { fiktif dalam } \\
\text { penjualan } \\
\text { tunai. }\end{array}$ & 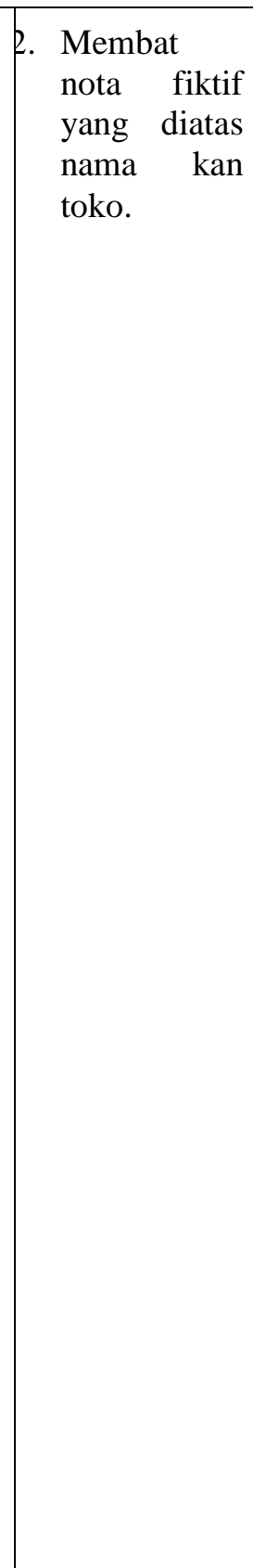 & $\begin{array}{l}\text { adalah } \\
\text { pembuatan } \\
\text { nota fiktif, } \\
\text { melipat } \\
\text { gandakan } \\
\text { nota tagihan, } \\
\text { mangkir dari } \\
\text { jam kerja } \\
\text { untuk kepentingan } \\
\text { pribadi, } \\
\text { adapula } \\
\text { kecurangan } \\
\text { yang } \\
\text { berbentuk } \\
\text { saling } \\
\text { meminjam } \\
\text { barang yang } \\
\text { dilakukan } \\
\text { oleh sales } \\
\text { yang bekerja } \\
\text { dalam satu } \\
\text { perusahaan } \\
\text { yang sama, } \\
\text { dan penggunaan } \\
\text { rekening } \\
\text { pribadi untuk } \\
\text { digunakan } \\
\text { sebagai alat } \\
\text { pembayaran } \\
\text { yang ternyata } \\
\text { uang yang } \\
\text { telah } \\
\text { ditransfer } \\
\text { tidak } \\
\text { disetorkan ke } \\
\text { perusahaan. }\end{array}$ \\
\hline $\begin{array}{l}\text { 2. Apa yang } \\
\text { membuat sales } \\
\text { melakukan } \\
\text { tindakan } \\
\text { kecurangan? }\end{array}$ & & & $\begin{array}{l}\text { Karena adanya } \\
\text { kesempatan } \\
\text { yang bisa } \\
\text { dimanfaatkan } \\
\text { untuk } \\
\text { melakukan } \\
\text { tindak } \\
\text { kejahatan, } \\
\text { selain itu } \\
\text { kecurangan } \\
\text { juga terjadi } \\
\text { karena sistem } \\
\text { pengendalian }\end{array}$ & $\begin{array}{l}\text { Adanya } \\
\text { kesempatan } \\
\text { dan peluang } \\
\text { yang membuat } \\
\text { salesman } \\
\text { dapat } \\
\text { melakukan } \\
\text { tindak } \\
\text { kecurangan } \\
\text { dengan } \\
\text { mengambil } \\
\text { uang hasil } \\
\text { tagihan nota }\end{array}$ & $\begin{array}{l}\text { Kecurangan } \\
\text { bisa terjadi } \\
\text { karena } \\
\text { beberapa } \\
\text { faktor seperti } \\
\text { ekonomi dan } \\
\text { gengsi akan } \\
\text { gaya hidup, } \\
\text { namun faktor } \\
\text { yang } \\
\text { mendorong } \\
\text { sales } \\
\text { melakukan }\end{array}$ \\
\hline
\end{tabular}




\begin{tabular}{|c|c|c|c|c|c|}
\hline & & & $\begin{array}{l}\text { dari } \\
\text { perusahaan } \\
\text { juga kurang } \\
\text { memadai, } \\
\text { kurangnya } \\
\text { pengecekan } \\
\text { piutang secara } \\
\text { langsung ke } \\
\text { lapangan } \\
\text { menjadi } \\
\text { pemicu } \\
\text { terjadinya } \\
\text { kecurangan } \\
\text { terhadap } \\
\text { perusahaan. }\end{array}$ & $\begin{array}{l}\text { perusahaan. } \\
\text { Ditambah lagi } \\
\text { dengan } \\
\text { pengendalian } \\
\text { atau kontrol } \\
\text { dari } \\
\text { perusahaan itu } \\
\text { sendiri juga } \\
\text { kurang } \\
\text { memadai, } \\
\text { sehingga } \\
\text { salesman } \\
\text { dengan } \\
\text { mudahnya } \\
\text { bisa } \\
\text { melakukan } \\
\text { tindak } \\
\text { kecurangan } \\
\text { terhadap } \\
\text { perusahaan. }\end{array}$ & $\begin{array}{l}\text { tindakan } \\
\text { kecurangan } \\
\text { adalah faktor } \\
\text { ekonomi } \\
\text { serta } \\
\text { pengawasan } \\
\text { dari } \\
\text { perusahaan } \\
\text { yang lemah } \\
\text { sehingga } \\
\text { sales terlena } \\
\text { dengan } \\
\text { adanya } \\
\text { kesempatan } \\
\text { sehingga } \\
\text { sales berani } \\
\text { melakukan } \\
\text { tindakan } \\
\text { kecurangan } \\
\text { terhadap } \\
\text { perusahaan. }\end{array}$ \\
\hline $\begin{array}{l}\text { 3.Bagaimana } \\
\text { tindakan } \\
\text { yang } \\
\text { dilakukan } \\
\text { oleh } \\
\text { perusahaa } \\
\mathrm{n} \text { dalam } \\
\text { menangan } \\
\text { i kasus } \\
\text { kecuranga } \\
\mathrm{n} \text { tersebut } \\
\text { ? }\end{array}$ & $\begin{array}{l}\text { Menyelesaik } \\
\text { an secara } \\
\text { kekeluargaan } \\
\text { harapan si } \\
\text { pelaku } \\
\text { kecurangan } \\
\text { mengganti } \\
\text { semua } \\
\text { kerugian atau } \\
\text { uang yang } \\
\text { telah } \\
\text { dipakainya. } \\
\text { Dikarenakan } \\
\text { pelaku tidak } \\
\text { mengembalik } \\
\text { an uang hasil } \\
\text { penagihan } \\
\text { piutang yang } \\
\text { digunakan, } \\
\text { maka PT. } \\
\text { Java Prima } \\
\text { Abadi akan } \\
\text { membawa } \\
\text { kasus tersebut ke } \\
\text { jalur hukum. }\end{array}$ & $\begin{array}{l}\text { Menyelesaik } \\
\text { an secara } \\
\text { kekeluargaan } \\
\text { terlebih } \\
\text { dahulu, dan } \\
\text { kemudian } \\
\text { baru } \\
\text { menyerahka } \\
\text { n kasus yang } \\
\text { ada kepada } \\
\text { pihak yang } \\
\text { berwajib. } \\
\text { Pada saat itu } \\
\text { Bapak } \\
\text { Irianto juga } \\
\text { menjelaskan } \\
\text { bahwa pihak } \\
\text { sales yang } \\
\text { melakukan } \\
\text { kecurangan } \\
\text { tidak dapat } \\
\text { membayar } \\
\text { atau memberikan } \\
\text { jaminan } \\
\text { apapun } \\
\text { untuk perusahaan. } \\
\text { mana }\end{array}$ & & & $\begin{array}{l}\text { Diselesaikan } \\
\text { dengan cara } \\
\text { kekeluargaan } \\
\text { terlebih } \\
\text { dahulu } \\
\text { karena sales } \\
\text { yang berbuat } \\
\text { curang tidak } \\
\text { dapat } \\
\text { mengganti } \\
\text { kerugian } \\
\text { yang telah } \\
\text { ditimbulkan } \\
\text { dari } \\
\text { kecurangan } \\
\text { maka jalan } \\
\text { terakhir yang } \\
\text { diambil } \\
\text { adalah } \\
\text { dilanjutkan } \\
\text { ke jalur } \\
\text { hukum. }\end{array}$ \\
\hline
\end{tabular}




\begin{tabular}{|c|c|c|c|c|c|}
\hline $\begin{array}{l}\text { 4.Bagaimana } \\
\text { bentuk } \\
\text { pengendalian } \\
\text { internal pada } \\
\text { PT. Java } \\
\text { Prima Abadi? }\end{array}$ & $\begin{array}{l}\text { Melakukan } \\
\text { pencocoka } \\
\mathrm{n} \text { antara } \\
\text { stok yang } \\
\text { dibawa } \\
\text { oleh sales } \\
\text { dengan } \\
\text { uang } \\
\text { setoran dan } \\
\text { nota } \\
\text { penjualan } \\
\text { yang } \\
\text { dilaporkan. }\end{array}$ & $\begin{array}{l}\text { Penagihan } \\
\text { piutang } \\
\text { diberi waktu } \\
\text { hingga 14 } \\
\text { hari dengan } \\
\text { syarat dan } \\
\text { ketentuan } \\
\text { tidak boleh } \\
\text { ada } \\
\text { pengambilan } \\
\text { dobel nota, } \\
\text { Stok opname } \\
\text { dilakukan } \\
\text { pada 1bulan } \\
\text { sekali yang } \\
\text { dilakukan } \\
\text { pada akhir } \\
\text { bulan. }\end{array}$ & $\begin{array}{l}\text { Dilak } \\
\text { ukan } \\
\text { pendekatan } \\
\text { antara atasan } \\
\text { dan bawahan } \\
\text { agar dapat } \\
\text { mengetahui } \\
\text { keadaan } \\
\text { yang terjadi } \\
\text { di lapangan,Bri } \\
\text { fing } \\
\text { dilakukan } \\
\text { setiap hari } \\
\text { agar dapat } \\
\text { memberikan } \\
\text { solusi dan } \\
\text { semangat } \\
\text { pada tim. }\end{array}$ & $\begin{array}{l}\text { Sales } \\
\text { mengontrol } \\
\text { dalam } \\
\text { memberikan } \\
\text { hutang kepada } \\
\text { pelanggan. }\end{array}$ & $\begin{array}{l}\text { Pengendalian } \\
\text { internal } \\
\text { dalam sebuah } \\
\text { perusahaan } \\
\text { amat sangat } \\
\text { diperlukan } \\
\text { dalam sebuah } \\
\text { perusahaan } \\
\text { untuk } \\
\text { menjalankan } \\
\text { kegiatan } \\
\text { operasional } \\
\text { perusahaan. } \\
\text { Sistem } \\
\text { pengendalian } \\
\text { ini berbeda - } \\
\text { beda antara } \\
\text { perusahaan } \\
\text { yang satu } \\
\text { dengan } \\
\text { perusahaan } \\
\text { yang lainnya } \\
\text { dan bergantung } \\
\text { beberapa } \\
\text { faktor, seperti } \\
\text { operasionaln } \\
\text { ya dan } \\
\text { besarnya } \\
\text { perusahaan. }\end{array}$ \\
\hline $\begin{array}{l}\text { 5.Bagaimana } \\
\text { bentuk } \\
\text { pengendalian } \\
\text { internal yang } \\
\text { efektif pada } \\
\text { PT. Java } \\
\text { Prima Abadi? }\end{array}$ & \begin{tabular}{l} 
t Audi \\
sering dapat \\
dilakukan. \\
\multicolumn{1}{c}{ Penc } \\
ocokan \\
Stok \\
dengan \\
laporan \\
penjualan. \\
\multicolumn{1}{c}{ Penc } \\
ocokan \\
uang hasil \\
penjualan \\
dengan sisa \\
stok harus \\
sesuai \\
dengan
\end{tabular} & 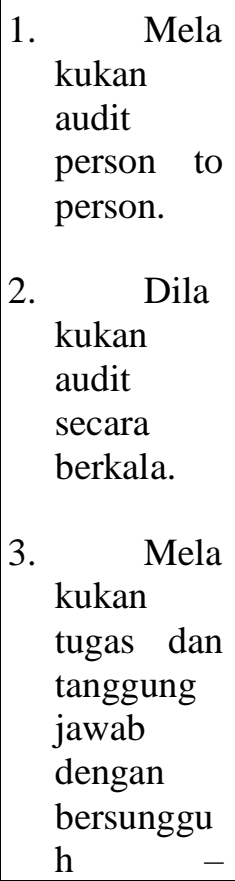 & $\begin{array}{l}\text { 1. Spv } \\
\text { dan manager } \\
\text { melakukan } \\
\text { pengecekan } \\
\text { nota } \\
\text { langsung ke } \\
\text { toko atau } \\
\text { konsumen. } \\
\text { 2. Menc } \\
\text { ocokan } \\
\text { stampel dan } \\
\text { tandatangan } \\
\text { pemilik toko } \\
\text { agar tidak } \\
\text { terjadi } \\
\text { pembuatan } \\
\text { nota fiktif. }\end{array}$ & \begin{tabular}{l} 
1. \\
secara \\
berkala. \\
2. Pudit \\
cokan nota \\
penjualan , \\
retur \\
penjualan \\
dengan \\
laporan \\
penjualan \\
sales. \\
\multicolumn{1}{c}{ Penco } \\
3. \\
cokan \\
pembayaran \\
dan nota \\
tagihan \\
dengan nota
\end{tabular} & $\begin{array}{l}\text { Pengendalian } \\
\text { internal yang } \\
\text { efektif yaitu } \\
\text { proses untuk } \\
\text { memastikan } \\
\text { bahwa } \\
\text { aktivitas } \\
\text { sebenarnya } \\
\text { sesuai dengan } \\
\text { aktivitas yang } \\
\text { direncanakan } \\
\text { dan bisa } \\
\text { mencapai } \\
\text { tujuan yang } \\
\text { maksimal } \\
\text { dari yang } \\
\text { diharapkan. }\end{array}$ \\
\hline
\end{tabular}




\begin{tabular}{|l|l|l|l|l|l|}
\hline & $\begin{array}{l}\text { laporan } \\
\text { penjualan } \\
\text { yang } \\
\text { dilaporkan. }\end{array}$ & sungguh. & & $\begin{array}{l}\text { yang } \\
\text { dimiliki } \\
\text { toko. }\end{array}$ & \\
\hline
\end{tabular}

Sumber : Dari Hasil Wawancara Dengan Informan.

\section{Pembahasan}

Sistem informsi akuntansi yang baik harus mempunyai suatu pengendalian. Sistem pengendalian internal yang diterapkan pada sistem informasi akuntansi sangat berguna untuk mencegah atau menjaga terjadinya kesalahan - kesalahan atau kecurangan - kecurangan. Sistem pengendalian internal juga dapat digunakan untuk melacak kesalahan - kesalahan yang terjadi sehingga dapat dikoreksi.

Dalam mengamati kasus kecurangan (fraud) yang terjadi di PT. Java Prima Abadi ini, perusahaan belum melakukan pengendalian internal yang baik dalam mencegah adanya fraud dalam perusahaan, pengendalian internal yang dilakukan perusahaan masih sangat kurang efektif, karena masih ditemukan adanya kecurangan yang terjadi pada divisi marketing atau sales, kecurangan yang timbul tersebut terjadi karena adanya tekanan, peluang, dan rasionalisasi. Sesuai dengan teori fraudtriangle yang mengatakan bahwa peluang kecurangan yang terjadi di PT. Java Prima Abadi disebabkan oleh adanya kesempatan atau peluang. Peluang itu sendiri timbul karena memang dari perusahaan ini sendiri masih lemah dalam pengendalian internalnya, sehingga ini dimanfaatkan oleh pihak yang tidak bertanggung jawab dalam malakukan kecurangan dengan mengambil uang tagihan untuk kepentingan pribadi mereka.

Adapun permasalahan yang muncul dalam kecurangan yang terjadi di PT. Java Prima Abadi antara lain :

1. Menggunakan nota fiktif, nota fiktif yang dimaksud merupakan nota yang tidak sebenarnya. Misalnya sales melakukan penjualan kepada Toko " A “ kemudian sales membuat nota yang sama dengan nota dari perusahaan, dan nota tersebut yang digunakan sales untuk melakukan penagihan piutang kepada konsumen jadi apabila sudah ada pembayaran perusahaan tidak curiga karena nota aslinya masih ada pada perusahaan. Untuk menghindari adanya nota fiktif yang dibuat oleh sales, sebaiknya perusahaan melakukan konfirmasi dengan menelepon konsumen untuk memastikan apakah sudah ada pembayaran atau belum untuk nota konsumen tersebut. 
2. Penggelembungan tagihan penjualan, penggelembungan yang dimaksud disini adalah misalnya sales melakukan penjualan ke Toko “ A " senilai lima juta rupiah seharusnya sales melaporkan dilaporan penjualan senilai lima juta rupiah tetapi digelembungkan menjadi dua kali lipat menjadi sepuluh juta rupiah agar mencegah adanya penggelembungan nota tagihan sebaiknya perusahaan melakukan cek stok pencocokan antara sisa stok dan laporan penjualan serta mengkonfirmasi tagihan pada pihak konsumen atau toko tersebut.

3. Uang setoran tidak disetorkan seluruhnya, hal ini disebabkan karena tidak ada pengawasan dan pengecekan berkala terhadap nota - nota hasil penagihan piutang. Sebaiknya untuk meminimalkan adanya kecurangan dengan tidak menyetorkan uang tagihan seluruhnya, dilakukan pengecekan pada nota. Nota yang telah dilaporkan harus sesuai dengan jumlah barang yang telah dijual dan sisa stok harus dicocokan dengan laporan yang telah dilaporkan oleh sales dengan begitu akan mencegah terjadinya tindak kecurangan.

4. Saling meminjam barang antar sales, saling meminjam barang ini sering dilakukan terutama pada sales yang bekerja pada satu perusahaan yang sama, hal ini dapat terjadi karena kurangnya pengawasan atau kontrol stok untuk mencegah agar tidak terjadi saling meminjam barang paling tidak dilakukan stok opname maximal 7 hari, dengan begitu akan memperkecil peluang untuk dapat melakukan saling meminjam barang antar sales.

5. Meminta pelanggan untuk melakukan pembayaran via transfer dan transfer diarahkan ke rekening sales. Sales memberikan informasi kepada konsumen untuk melakukan pembayaran secara transfer ke rekening sales itu sendiri dengan alasan untuk menghindari apabila ada pemeriksaan pajak. Dalam mengatasi kejadian seperti ini, sebaiknya perusahaan mencantumkan nomor rekening perusahaan pada nota agar konsumen bisa melakukan transfer ke rekening perusahaan serta dicantumkan nomer telpon perusahaan agar konsumen bisa melakukan konfirmasi apabila akan melakukan pembayaran piutang dengan cara transfer.

6. Mangkir pada saat jam kerja, hal ini kerap dilakukan oleh sales yang sering menggunakan waktu jam kerja untuk bersantai atau nongkrong untuk mencegah terjadinya mangkir ini sebaiknya perusahaan dapat dengan melakukan pendekatan terhadap para sales memberikan motivasi dan semangat untuk dapat melakukan tugas 
dan tanggung jawab sebagai sales serta memberikan masukan - masukan atas kendala yang terjadi dilapangan agar sales juga dapat mengejar target yang diberikan oleh perusahaan.

Kecurangan yang terjadi pada perusahaan ini disebabkan karena karyawan mengalami kebutuhan ekenomi yang mendesak. Kemudian berkaitan dengan hubungan keagenan suatu kontrak dimana satu atau lebih orang (prinsipal) memerintah orang lain (agen) untuk melakukan suatu jasa atas nama prinsipal serta memberi wewenang kepada agen membuat keputusan yang terbaik bagi prinsipal.

Pada kasus kecurangan (fraud) terhadap piutang usaha yang terjadi di PT. Java Prima Abadi, perusahaan amat sangat dirugikan. Perusahaan mengalami kerugian di tahun 2017 s/d 2018 sebesar Rp. 50.546.700,-. Jika diukur dengan materialitas perusahaan menganggap kerugian yang dialami meresahkan dan menganggu keuangan dari PT. Java Prima Abadi. Materialitas merupakan kadar atau ambang batas atas hilangnya informasi keuangan atau ketidak benaran informasi dalam laporan keuangan, yang mana informasi tersebut dianggap akan memiliki dampak yang cukup besar bagi para pengguna laporan keuangan dalam mengambil keputusan.

\section{Penutup}

\section{Kesimpulan}

Perusahaan berkembang pada saat ini melakukan berbagai macam cara dalam hal penjualan agar bisa memperoleh laba yang maksimal. Tidak sedikit perusahaan yang melakukan penjualan secara kredit. Terdapat resiko yang cukup besar dengan adanya penjualan kredit, antara lain kredit macet, konsumen tidak mau melunasi hutang nya dan kecurangan (fraud). Dari kasus di atas kecurangan yang terjadi pada perusahaan di PT. Java Prima Abadi adalah dilakukan oleh sales. Kecurangan yang terjadi adalah dengan tidak menyetorkan hasil penagihan piutang ke kantor namun di gunakan untuk keperluan pribadi.

Dalam sebuah perusahaan, pengendalian internal sangat di perlukan. Sistem pengendalian internal harus di terapkan dengan baik agar kecenderungan kecurangan yang di temukan di PT. Java Prima Abadi dapat di cegah dan di 
minimalisir. Pengendalian internal yang harus dilakukan oleh PT. Java Prima Abadi yaitu :

1. Pembagian job description untuk masing - masing bagian.

2. Melakukan audit atau pengecekan secara rutin untuk sisa stock, retur, laporan penjualan dan uang hasil penjualan.

3. Melakukan survei langsung ke lapangan untuk mengantisipasi kecurangan terhadap penagihan piutang dan pemalsuan tanda tangan toko atau konsumen.

Efektivitas adalah kemampuan melaksanakan tugas, fungsi (operasi kegiatan program atau misi) dari pada suatu organisasi atau sejenisnya yang tidak adanya tekanan atau ketegangan di antara pelaksananya. Sedangkan pengendalian internal, control merupakan serangkaian tindakan, baik dalam bentuk prosedur, kebijakan maupun metode, untuk memberi kepastian yang memadai bagi manajemen bahwa organisasi akan mampu mencapai tujuannya, diantaranya menjaga kekayaan organisasi, dan tercapainya efektivitas dan efisiensi operasi.

Menganalisa kasus kecurangan (fraud) terhadap karyawan terutama pada sales di PT. Java Prima Abadi, peneliti menggunakan teori untuk menyesuaikan theory fraud triangle dan theory agency sehingga sistem pengendalian internal yang lemah dan manajemen pengewasan yang kurang memadai harus mampu untuk antisipasi sehingga tidak ada lagi kecurangan yang terjadi dalam perusahaan.

\section{Saran}

Berdasarkan hasil analisis pembahasan yang telah dilakukan maka terdapat beberapa hal yang dapat di sarankan antara lain :

1. Bagi perusahaan PT. Java Prima Abadi, seharusnya perusahaan melakukan pengendalian internal yang benar - benar efektif, perusahaan harus sering melakukan pengecekan kinerja karyawan - karyawannya supaya jangan sampai ada celah yang bisa digunakan untuk melakukan tindakan kecurangan (fraud).

2. Persuhaan harus mempunyai auditor dari luar perusahaan yang nantinya bertugas melakukan pengecekan semua kinerja dari karyawan, sehingga bisa mencegah adanya tindak kecurangan dari karyawan. 
3. Pemimpin perusahaan seperti supervisor, harus sering melakukan kunjungan langsung ke lapangan untuk mengetahui kinerja dari salesnya.

4. Pembagia job discription yang jelas pada masing - masing bagian agar semua mengerti tanggung jawabnya masing - masing.

5. Adanya pengawasan yang lebih ketat terhadap semua kinerja dari semua karyawan perusahaan.

6. Bagi karyawan terutama sales diharapkan tidak melakukan tindak kecurangan (fraud) karena bekerja yang tidak di dasari kejujuran akan merugikan diri sendiri dan orang lain. Tanamkan pada diri anda sikap prifesionalisme karena sikap profesianalisme itu harus di terapkan pada semua aspek kehidupan. Berlakulah jujur, karena kejujuran akan membawa keberkahan dan kecurangan awal dari kerugian.

\section{Keterbatasan Penelitian}

Dalam penelitian terdapat keterbatasan selama proses penelitian diantaranya

1. Waktu penelititan yang relatif pendek, sehingga pengematan terhadap pelaku kecurangan menjadi terbatas.

2. Keengganan informan untuk tidak memberikan informasi yang lebih detail tentang tindakan kecurangan yang dilakukan.

3. Penelitian hanya dilakukan pada satu perusahaan.

\section{Agenda Penelitian Selanjutnya}

Sebagai rekomendasi untuk penelitian selanjutnya, penulis menyarankan untuk :

1. Mengkaji lagi lebih dalam penyebab kecurangan (fraud) terhadap karyawan perusahaan secara kuantitatif, gunan meningkatkan hasil penelitian yang lebih realiable.

2. Mengkaji tentang tingkat pengendalian internal dengan potensi adanya kecurangan (fraud). 


\section{DAFTAR PUSTAKA}

Arens, A. A. (2011). Auditing Dan Jasa Asurance Jilid 2 Edisi Ke 12. Jakarta: Salemba Empat.

Aridhianto, N. C. (2015). Analisis Kondisi Fasilitas Belajar Dan Motivasi Belajar Siswa Kelas Atas. Jurnal Pendidikan Guru Sekolah Dasar Edisi 13 Tahun ke IV Agustus 2015 , 5-11.

CITATION Suk14 VI 1057 (Agoes, 2014) Auditing Edisi ke 42014JakartaSalemba Empat

Budiyoni, E. (2018). Studi Tentang Teori Gone dan Pengaruhnya Terhadap Fraud Dengan Idealisme Pimpinan Sebagai Variabel Moderasi : Studi Pada Pengadaan Barang/Jasa di Pemerintahan . Jurnal Dinamika Akuntansi dan Bisnis Vol.5 (1) , 31-42.

Fadlan, M. (2018). Pendekatan Dalam Menilai Internal Control System Pada Pemanfaatan Teknologi Informasi : Sebuah Kajian Pustaka. Jurnal Instek Informatika Sains Dan Teknologi , 181-190.

Lawrence B. Sawyer, J. C. (2009). Sawyer's Internal Auditing Edisi 1 Buku 5. Jakarta: Salemba Empat.

Suginam. (2017). Pengaruh Peran Audit Internal Dan Pengendalian Intern Terhadap Pencegahan Fraud. Riset Dan Jurnal Akuntansi , 22-28.

Sutrischastini, A. (2015). Pengaruh Motivasi Kerja Terhadap Kinerja Pegawai Kantor Sekretariat Daerah Kabupaten Gunungkidul. Jurnal Kajian Bisnis Vol.2, No.2, 121-137. 
Halaman ini sengaja dikosongkan 